Hautarzt 2016 $67: 666$

DOI 10.1007/s00105-016-3859-2

Online publiziert: 28. Juli 2016

(c) Springer-Verlag Berlin Heidelberg 2016

CrossMark
M. Augustin $\cdot$ Z. Anastasiadou' $\cdot$ M. L. Schaarschmidt ${ }^{1} \cdot$ M. Krensel ${ }^{1} \cdot$ I. Schäfer ${ }^{1}$. M. Reusch ${ }^{2}$

'Institut für Versorgungsforschung in der Dermatologie und bei Pflegeberufen (IVDP), Universitätsklinikum Hamburg-Eppendorf (UKE), Hamburg, Deutschland

${ }^{2}$ Dermatologische Gemeinschaftspraxis am Tibarg, Hamburg, Deutschland

\section{Erratum zu: Versorgung des Hautkrebses in Deutschland. Leistungsvolumina und -erbringer}

\section{Erratum to: Health care for skin cancer in Germany. Provision and providers}

\section{Abstract}

oben genannten Beitrags fehlerhaft abgedruckt. Der korrekte englische Titel lautet: „Health care for skin cancer in Germany. Provision and providers". Wir bitten Sie, die richtige Version zu berücksichtigen.

Die Redaktion

\section{Korrespondenzadresse}

\section{Prof. Dr. M. Augustin}

Institut für Versorgungsforschung in der Dermatologie und bei Pflegeberufen (IVDP), Universitätsklinikum Hamburg-Eppendorf (UKE)

Martinistr. 5, 20246 Hamburg, Deutschland m.augustin@uke.de

Die Online-Version des Originalbeitrags findet sich unter http://dx.doi.org/10.1007/s00105016-3816-0.
Hautarzt DOI 10.1007/s00105-016-3859-2

c) Springer-Verlag Berlin Heidelberg 2016

M. Augustin · Z. Anastasiadou · M. L. Schaarschmidt · M. Krensel · I. Schäfer · M. Reusch Health care for skin cancer in Germany. Provision and providers

Abstract

Background. Treatment for skin cancer is a major component of dermatological care in western countries.

Objective. The purpose of this work is to analyze health care provision and providers for skin cancer care in Germany.

Methods. From the complete claims data set from 2007-2009 of the German statutory health insurance DAK (approximately 6.1 million insured persons), insurees with skin cancer and melanocytic naevi were extracted by ICD-10 codes. Surgical procedures and physician specialties were identified by specific codes. Data from the German statistical agency (Destatis) were derived from public domain for the years 2008-2010.

Results. Among the annual ambulatory surgical treatments $(n=6695)$ for melanoma, $83.6 \%$ were conducted by dermatologists, followed by general surgeons $(11.1 \%)$, and facial surgeons (3.0\%). In melanocytic naevi $(n=51,659), 79.1 \%$ were treated by dermatologists, followed by general surgeons $(15.5 \%)$, facial surgeons (3.6\%), and general practitioners $(1.1 \%)$, while in epithelial cancers (ICD-10 C44), 76.4\% were operated by dermatologists, followed by general surgeons (12.7\%) and facial surgeons (7.9\%). Overall, related to Germany, about 830,000 ambulatory operations for skin cancer were conducted in 2009 which is about $40 \%$ more than in 2007. In hospitalized patients, 79,448 out of 195,558 inpatient cases (45.5\%) were treated in dermatological departments in the year 2012. Average annual growth rates of the inpatient cases in the DAK between 2007 and 2010 were $8.9 \%$ for MM and $11.1 \%$ for SCC/BCC.

Conclusion. Skin cancer is associated with a significant and still growing need for surgical care in which dermatology has a leading role in Germany. Thus, there is an increasing need for dermato-surgical specialist training.

\section{Keywords}

Melanoma - Basal cell carcinoma $\cdot$ Squamous cell carcinoma - Dermatologists · Surgical procedures, operative 